\title{
COMPUTER AID IN INTENSIVE CARE
}

\author{
Roger Meloche, M.D., "Jacques R. Boucher, M.d., "Adele Bedrossian, m.d.† and \\ Nadim RaphaEl, M.D. $†$
}

FOR MANY YEARS, prolonged mechanical ventilation has proven to be lifesaving. At first, the iron lung was used during poliomyelitis epidemics to treat respiratory paralysis. ${ }^{1}$ In 1955 , the respirator helped in treatment of respiratory failure after lung resection, ${ }^{2-3}$ open-heart surgery and multiple fractures and injuries. ${ }^{4-5}$ The merits of the respirator in preventing hypoxaemia and respiratory acidosis are no longer debated. ${ }^{6,7,8}$ The number of patients in intensive care units who need mechanical respiratory assistance is ever increasing. Pontoppidan has written interesting facts on frequency and cost of this treatment. ${ }^{9}$

However, prolonged mechanical ventilatory assistance has generated complications which did not previously exist, such as "respirator lung." These patients often need high inhaled oxygen percentages, and the toxic effects of high oxygen tensions on pulmonary tissue are well documented. ${ }^{10-11}$ Sladen has indicated that mechanical ventilation could be associated with water retention, which changes the compliance and the ventilation-perfusion ratio. ${ }^{12}$

Physiopathology of the "respirator lung" is difficult to elucidate. Most of the affected patients present other problems such as clogging of the microcirculation, loss of integrity of the capillary membrane and other disturbances of homeostasis such as hypoproteinaemia, cardiac failure, shock, adrenal insufficiency and inappropriate secretion of ADH. After a well documented study, Nash et al. concluded that the morphological changes encountered in the "respirator lung" related to prolonged use of artificial ventilation combined with high oxygen concentration of the breathing mixture. ${ }^{13}$ Pontoppidan, in a recent review article on respiratory insufficiency, stated that mechanical ventilation does not increase oxygen toxicity, but delays and even prevents its occurrence. ${ }^{9}$

Patients on respirators and more particularly post-operative and polytraumatized cases have a very unstable cardiopulmonary state. Transport and consumption of oxygen vary frequently. Thus $\mathrm{F}_{\mathrm{IO}_{2}}$ must be constantly adjusted. To give these patients the best possible care, one must be able to assess the needs rapidly, the carrying capacity and the rate of consumption of oxygen, as well as cardiac function, pulmonary gas exchange and cost of breathing. As a rule, these parameters are obtained from time-consuming pulmonary function studies and haemodynamic laboratory determinations.

A computer program has been devised to perform the complex calculations of the Riley-Cournand analysis correctly and rapidly. Through a terminal (Telex), it becomes possible to feed a computer (IBM 1800 with transcription interface) with

"Department of Anaesthesia, Hôpital Notre-Dame, Montréal.

†Faculté de Médecine Française, Beyrouth. 
HND INFORMATIQUE-TELEX-12/03/73/ 15HR57

DEMANDEZ VOTRE PROGRAMME.

ANESTHESIE

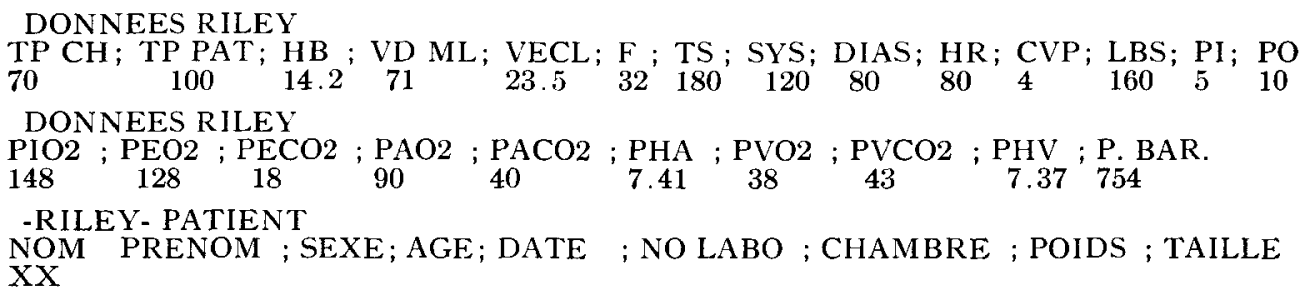

-RILEY- EXECUTION,

$\begin{array}{cr} & \\ \text { TEMP. PIECE F } & 70.0 \\ \text { TEMP. PATIENT } & 100.0 \\ \text { TEMP PIECE } & 21.1 \\ \text { TEMP. PATIENT } & 37.7 \\ \text { HEMOGLOBINE GM } & \mathbf{1 4 . 1} \\ \text { VDAPP. ML } & 70.9 \\ \text { VOL. COLLECTE } & 23.4 \\ \text { RYTHME } & 31.9 \\ \text { TEMPS VOLUME } & \\ \text { COL. ET RYTHME } & \mathbf{1 7 9 . 9} \\ \text { PIO2 } & \mathbf{1 4 7 . 9} \\ \text { PEO2 } & \mathbf{1 2 7 . 9} \\ \text { PECO2 } & \mathbf{1 7 . 9} \\ \text { PAO2 } & \mathbf{9 0 . 0} \\ \text { PACO2 } & 40.0 \\ \text { PHA } & \mathbf{7 . 4 0 9} \\ \text { PVO2 } & 37.9 \\ \text { PVCO2 } & 42.9 \\ \text { PHV } & \mathbf{7 . 3 6 9} \\ \text { PRESSION BAR. } & 753.99\end{array}$

PRESSION SYS.

PRESSION DIAS.

RYTHME CARDIA.

CVP

POIDS

TAILLE PI

TAILLE PO

\begin{tabular}{|c|c|c|}
\hline \multicolumn{3}{|c|}{ RESULTATS } \\
\hline \multirow{2}{*}{\multicolumn{2}{|c|}{$\begin{array}{l}\text { VE ATPS L/M } \\
\text { FREOUENCE }\end{array}$}} & 7833.3 \\
\hline & & 10.6 \\
\hline \multicolumn{2}{|c|}{ VE BTPS ML/MIN } & 8609.3 \\
\hline \multicolumn{2}{|c|}{ VT BTPS ML } & 807.1 \\
\hline & 1.111 \\
\hline \multicolumn{2}{|c|}{$\begin{array}{c}\text { FILLEY FACTOR } \\
\text { FEO2 }\end{array}$} & 0.181 \\
\hline & FIO2 & 0.209 \\
\hline \multicolumn{2}{|c|}{$\mathrm{FECO} 2$} & 0.025 \\
\hline \multicolumn{2}{|c|}{ VO2STPD L/MN/M2 } & 107.2 \\
\hline \multirow[t]{5}{*}{$\mathrm{VCO} 2$} & STPD/M2 & 94.0 \\
\hline & RAPPORT & 0.876 \\
\hline & VD BTPS & 385.0 \\
\hline & VD/VT & 47.70 \\
\hline & PAÁO2 & 102.0 \\
\hline \multirow[t]{8}{*}{ DIF. } & ALV. ART. & 8.4 \\
\hline & $\mathrm{SAO} 2$ & 96.80 \\
\hline & $\mathrm{CAO} 2$ & 18.69 \\
\hline & SVO2 & 68.46 \\
\hline & $\mathrm{O} 2$ & 13.14 \\
\hline & $\mathrm{SAAO} 2$ & 97.57 \\
\hline & $\mathrm{CCO} 2$ & 18.87 \\
\hline & QS/QT & 3.029 \\
\hline \multirow[t]{9}{*}{ DIF. } & ART. VEINEUX & 5.55 \\
\hline & & 3.66 \\
\hline & $\mathrm{CO} 2$ & 41.3 \\
\hline & PVCO2 & 44.4 \\
\hline & PHA & 7.398 \\
\hline & & 7.358 \\
\hline & $\mathrm{O} 2$ & 40.2 \\
\hline & $\mathrm{PAO} 2$ & 93.5 \\
\hline & Q VD/VT & 52.08 \\
\hline \multirow[t]{8}{*}{ SURF. } & CORP.M2 & 1.89 \\
\hline & MAP & 93.3 \\
\hline & SV & 45.84 \\
\hline & CI & 1.93 \\
\hline & SVR & 1946.51 \\
\hline & SI & 24.15 \\
\hline & VA & 4501.93 \\
\hline & & 1.22 \\
\hline
\end{tabular}

Figure 1.

readily available information from analysis of expired, arterial and venous blood gases, and to obtain immediately results that normally would require hours of difficult calculations. It takes only 30 minutes for a physician assisted by a nurse to get the samples and to have them analyzed by one laboratory technician, before receiving from the computer the results listed in Figure 1. 
The main advantage in using a teleprinter is speed. It also eliminates transcription errors and makes it possible for remote hospitals to use the computer program. This program is not very complex and is similar to the one published by Föex, Meloche and Prys-Roberts. ${ }^{14}$ Kelman's sub-routine for calculating saturations is used without modification. ${ }^{15}$ However, in this program more data are fed in and hence more results are obtained.

\section{Method of Sampling}

Before operation, a catheter is inserted by cutdown in the antecubital vein and positioned in the superior vena cava. A microcatheter (microcath, procédé Electronique Marcel Dassault) is then passed through the previous catheter and floated into the pulmonary artery. Its position is monitored on an oscilloscope using a pressure transducer. ${ }^{16}$ More recently, the Swan-Ganz balloon tipped catheter has proven more reliable and easier to position with the help of a pressure transducer. ${ }^{17}$ A radial artery is also cannulated after ascertaining the flow in the ulnar artery. While the patients remain in I.C.U., their arterial and central venous or pulmonary wedge pressures and the EKG are constantly monitored on a Dassault monitor $V$ with Statham P23dB pressure transducers.

Blood sampling is performed with a $5 \mathrm{ml}$ glass syringe, cooled to $4^{\circ} \mathrm{C}$ with the dead space filled with a solution of heparin (1000 unit/ml). Expired gases are collected in a 60-liter Douglas bag, after the patient has been breathing room air in the same horizontal position for at least one hour. The tracheal tube is connected to a low resistance one-way Rudolph valve (dead space, $20 \mathrm{ml}$ ). After breathing for a few minutes through the apparatus until the respiration has become quiet and regular, the expired gas is directed to the Douglas bag and collected for two or three minutes, while counting the respiratory rate and taking the blood samples.

\section{ANALYSIS}

Partial pressures of oxygen in blood are measured with a Clark electrode $\left(\mathrm{PO}_{2}\right.$ electrode, Type E 5046, Radiometer) previously calibrated against a solution of sodium sulfite and a mixture of 20 per cent glycerin in water equilibrated with room air. ${ }^{18}$ Partial pressures of $\mathrm{CO}_{2}$ are measured with a Severinghaus electrode ${ }^{19}$ (Type E 5036, Radiometer) and compared with Astrup's equilibration method using Siggaard-Andersen nomogram. ${ }^{20}$ Equilibrating and calibrating gases are analyzed by the method of Scholander..$^{21} \mathrm{Blood} \mathrm{pH}$ is measured at $37^{\circ} \mathrm{C}$ by a glass electrode coupled with the CO. electrode (Radiometer PHM 71). The glass electrode is calibrated with standard buffers (U.S. National Bureau of Standards). Analyses are made immediately after sampling and corrected for the difference of temperature between patient and electrode, according to Kelman and Nunn.22 Expired oxygen is measured by a paramagnetic analyser (Beckman E2) calibrated with known gases, or by Scholander's method. Expired $\mathrm{CO}_{2}$ is measured with a Severinghaus electrode or a Scholander apparatus. The volume of expired gas is measured by a gas meter (American Dry test Meters) that has been previously 
calibrated against a Tissot spirometer (constant 10 liter $/ \mathrm{min}$ Flow). These volumes are corrected to BTPS or STPD according to room temperature. Haemoglobin is measured by spectrophotometry (error: $0.1 \mathrm{gm} \mathrm{Hb} / 100 \mathrm{ml}$ ).

\section{Calculations}

All data are calculated and corrected by computer (IBM 1800). The following equations are used in the programming:

1. Dead space: Bohr's equation modified by Enghoff ${ }^{23}$

$$
\mathrm{V}_{\mathrm{D}}=\mathrm{V}_{\mathrm{T}} \frac{\mathrm{Pa}_{\mathrm{CO}_{2}}-\mathrm{PE}_{\mathrm{CO}_{2}}}{\mathrm{~Pa}_{\mathrm{CO}_{2}}}-\mathrm{V}_{\mathrm{D}} \text { apparatus }
$$

2. Alveolar $\mathrm{PO}_{2}$, Nunn's equation $(1963)^{24}$

$$
\mathrm{PA}_{\mathrm{O}_{2}}=\mathrm{PI}_{\mathrm{O}_{2}}-\mathrm{Pa}_{\mathrm{CO}_{2}} \frac{\mathrm{PI}_{\mathrm{O}_{2}}-\mathrm{P}_{\mathrm{E}_{2}}}{\mathrm{PE}_{\mathrm{CO}_{2}}}
$$

3. Pulmonary Shunting: Berggren (1942) ${ }^{25}$

$$
\dot{\mathrm{Q}} \mathrm{s} / \dot{\mathrm{Q}} \mathrm{t}=\frac{\mathrm{CC}_{\mathrm{O}_{2}}-\mathrm{Ca}_{\mathrm{O}_{2}}}{\mathrm{C}_{\mathrm{O}_{2}}-\mathrm{C}_{\mathrm{V}_{2}}} \times 100
$$

4. Oxygen consumption: Riley ${ }^{26}$

5. $\mathrm{CO}_{2}$ output

$$
\dot{\mathrm{VO}}_{2}=\mathrm{VE} \frac{1-\mathrm{FE}_{\mathrm{O}_{2}}-\mathrm{F}_{\mathrm{E}_{\mathrm{C}_{2}}}}{1-\mathrm{F}_{\mathrm{I}_{2}}} \times \mathrm{FI}_{\mathrm{O}_{2}}-\left(\dot{\mathrm{VE}} \times \mathrm{FE}_{\mathrm{O}_{2}}\right)
$$

$$
\dot{\mathrm{V}} \mathrm{CO}_{2}=\mathrm{VE} \times \overrightarrow{\mathrm{FE}} \overline{\mathrm{CO}}_{2}
$$

6. Cardiac output is computed according to Fick's principle $(1870)^{27}$

$$
\dot{\mathrm{Q}}=\mathrm{VO}_{2} / \mathrm{Ca}_{\mathrm{O}_{2}}-\mathrm{C}_{\overline{\mathrm{V}}} \mathrm{O}_{2}
$$

Oxygen content $\left(\mathrm{CO}_{2}\right)$ in blood is the amount of haemoglobin-linked oxygen plus the amount in physical solution in plasma at $37^{\circ} \mathrm{C}$. One gram of haemoglobin can carry $1.39 \mathrm{ml}$ of oxygen ${ }^{28}$ and $100 \mathrm{ml}$ of whole blood can dissolve $0.003 \mathrm{ml}$ $\mathrm{O}_{2} / \mathrm{mmHg}$. Haemoglobin saturation is derived from the haemoglobin dissociation curve (Severinghaus, 1966). ${ }^{29}$ These figures are corrected for acid-base changes according to Kelman's sub-routine..$^{30-31}$

\section{Discussion}

Venous blood sampling cannot be done indifferently from the right atrium or pulmonary artery. Table I illustrates important differences in oxygen content between blood sampled in the right atrium and the pulmonary artery, the saturation varying from 4 per cent to 5 per cent. Samples from the atrium, close to the coronary sinus show a significant difference in saturation, hence in oxygen content, compared with blood drawn from the junction of the atrium and the inferior vena cava. However, the difference in saturation between the right ventricle and the 
TABLE I

Results From Blood Sampling in the Right Atrium and the Pulmonary Artery, Which is Made Possible Using a Triple Lumen Balloon-tipped Swan-Ganz Catheter

\begin{tabular}{|c|c|c|}
\hline & $\mathrm{AP}$ & OD \\
\hline $\begin{array}{l}\mathrm{PaO}_{2} \text { Torr. } \\
\mathrm{SaO}_{2} \% \\
\mathrm{CaO}_{2} \mathrm{ml} / 100 \mathrm{ml} \\
\mathrm{PvO}_{2} \mathrm{Torr} . \\
\mathrm{SvO}_{2} \% \\
\mathrm{CvO}_{2} \mathrm{ml} / 100 \mathrm{ml} \\
\mathrm{Qs} / \mathrm{Qt} \% \\
\mathrm{~A}-\mathrm{diff} \mathrm{ml} / 100 \mathrm{ml} \\
\mathrm{Qt} \mathrm{litres} / \mathrm{min} \\
\mathrm{SV} \mathrm{ml} \\
\mathrm{SVR} \text { dynes } / \mathrm{sec} / \mathrm{cm}^{-5}\end{array}$ & $\begin{array}{c}56.2 \\
0.89 \\
15.9 \\
37 \\
0.69 \\
12.4 \\
32 \\
3.52 \\
7.17 \\
71.7 \\
1092\end{array}$ & $\begin{array}{c}56.2 \\
0.89 \\
15.9 \\
41 \\
0.75 \\
13.4 \\
40.9 \\
2.48 \\
10.2 \\
102 \\
767\end{array}$ \\
\hline
\end{tabular}

TABLE II

Illustrates Improved Oxygen Carrying Capacity Following the DRaINAGE OF A LEFT HaEMoThoraX

\begin{tabular}{|c|c|c|c|}
\hline \multicolumn{4}{|c|}{$\begin{array}{l}\text { Male: } 20 \text { years (attempted suicide) Gunshot wound - Pulmonary } \\
\text { Contusions }\end{array}$} \\
\hline & $12-01-73$ & 12-01-73 a.m. & 12-01-73 p.m \\
\hline VT ml BTPS & 237 & 231 & 259 \\
\hline VD ml BTPS & 72 & 116 & 130 \\
\hline $\mathrm{Vd} / \mathrm{Vt}$ & 0.30 & 0.32 & 0.35 \\
\hline $\mathrm{VA}$ litres/min & 8.3 & 7.4 & 8.0 \\
\hline $\mathrm{Va} / \mathrm{Qt}$ & 2.03 & 1.96 & 1.14 \\
\hline $\mathrm{Qs} / \mathrm{Qt} \%$ & 0.47 & 0.29 & 0.30 \\
\hline $\mathrm{AaDO}_{2}$ Torr & 63 & 49 & 44 \\
\hline $\mathrm{PaO}_{2}$ Torr & 41 & 49.9 & 55.2 \\
\hline $\mathrm{PaCO}_{2}$ Torr & 37 & 41 & 42 \\
\hline $\mathrm{CaO}_{2} \mathrm{ml} / 100 \mathrm{ml}$ & 18 & 17 & 16.6 \\
\hline $\mathrm{A}-\mathrm{V}$ diff $\mathrm{ml} / 100 \mathrm{ml}$ & 5.71 & 6.36 & 3.88 \\
\hline $\mathrm{VO}_{2} \mathrm{ml} / \mathrm{min} / \mathrm{m}^{2} \mathrm{STPD}$ & 112 & 116 & 130 \\
\hline $\mathrm{VCO}_{2} \mathrm{ml} / \mathrm{min} / \mathrm{m}^{2} \mathrm{STPD}$ & & 93 & 108 \\
\hline $\mathrm{R}$ & 0.87 & 0.80 & 0.82 \\
\hline$Q$ litres/min & 4.09 & 3.79 & 7.00 \\
\hline$\widetilde{\mathrm{R}} \mathrm{C}$ & 150 & 146 & 152 \\
\hline $\mathrm{SV} \mathrm{ml}$ & 27 & 25 & 46 \\
\hline MAP Torr & $\overrightarrow{60}$ & 65 & 73 \\
\hline SVR dynes $/ \mathrm{sec} / \mathrm{cm}^{-5}$ & 1073 & 1242 & 745 \\
\hline $\mathrm{CaO}_{2} \mathrm{ml} / \mathrm{min}$ & 735 & 642 & 1160 \\
\hline
\end{tabular}

pulmonary artery is not significant. Table I shows results given from blood sampling in the right atrium and the pulmonary artery, which is made possible using a triple lumen balloon-tipped Swan-Ganz catheter.

Table II illustrates improved oxygen carrying capacity following the drainage of a left haemothorax. The patient, a 20-year-old man had suffered important abdominal damage following a gunshot wound: splenectomy, left hemicolectomy, closure of many bowel perforations and colostomy. The chest X-ray revealed a contused left lower lobe, pleural effusion and a shifted mediastinum. Before pleurostomy, he presented a severe tachycardia and marked hypoxaemia. A Riley- 

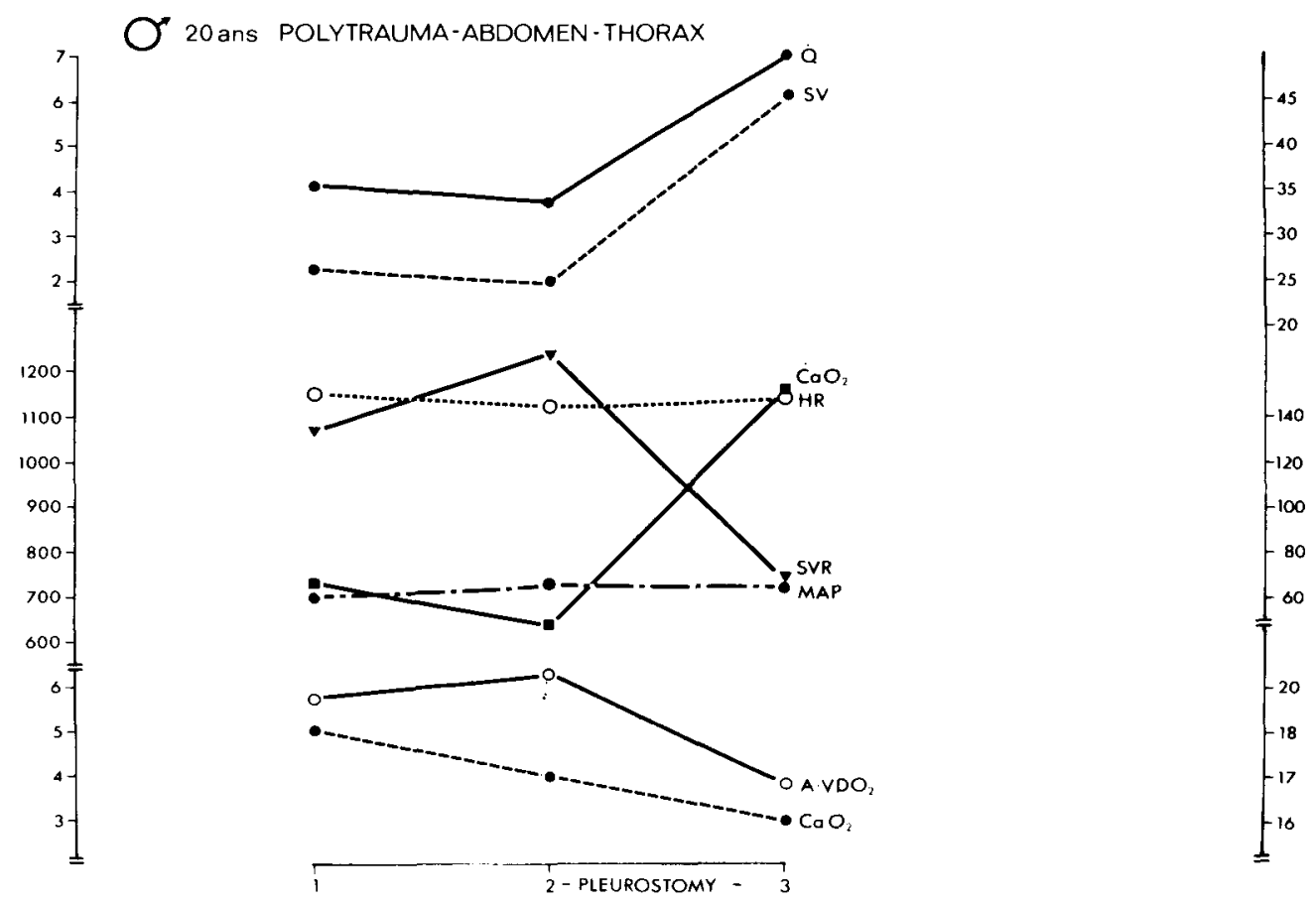

Figure 2. Haemodynamic changes after relief of mechanical displacement of mediastinum.

Cournand analysis gave more information, showing a decreased cardiac output resulting from an impaired stroke volume. After pleurostomy, the heart returned. to its normal position and function was improved. The results show an increase in ventilation and $\mathrm{Pa}_{2}$ and a decrease of the shunt and alveolar-arterial difference. However, the haemodynamic changes are more striking, the stroke volume and the available oxygen being almost doubled (Figures 2 and 3 ).

Table III illustrates a case of acute vascular overload after resection of an aneurysm of the abdominal aorta. Surgery of the aorta usually brings about important per-operative and post-operative fluid losses. On the day of operation and the first 12 hours after operation this 66 year old woman received a total of $4400 \mathrm{ml}$ of fluid to replace per-operative loss of $1000 \mathrm{ml}$, insensible loss of about $1500 \mathrm{ml}$ (36 hours) and $1905 \mathrm{ml}$ of urine. During the following night the blood pressure went up to $180 \mathrm{mmHg}$ systolic and a heart rate of $100 / \mathrm{min}$. She was calm and showed no radiological or auscultatory signs of pulmonary overload. However, in the morning one could hear a systolic murmur that had not been noticed before the operation, and the B.P. rose to $200 / 0$. The Riley-Cournand analysis showed a hyperkinetic state that was rather surprising in a woman of that age; the cardiac output being 12 litres/min with a stroke volume of $121 \mathrm{ml}$ and a total peripheral resistance of 700 dynes.secs.cm ${ }^{-5}$. The patient was then given $20 \mathrm{mg}$ of furosemide intravenously and, after a diuresis of $600 \mathrm{ml}$, the cardiac output and peripheral resistance became normal. One must point out that a decrease of 50 per cent of 
MELOCHE, et al.: COMPUTER AID IN INTENSIVE CARE
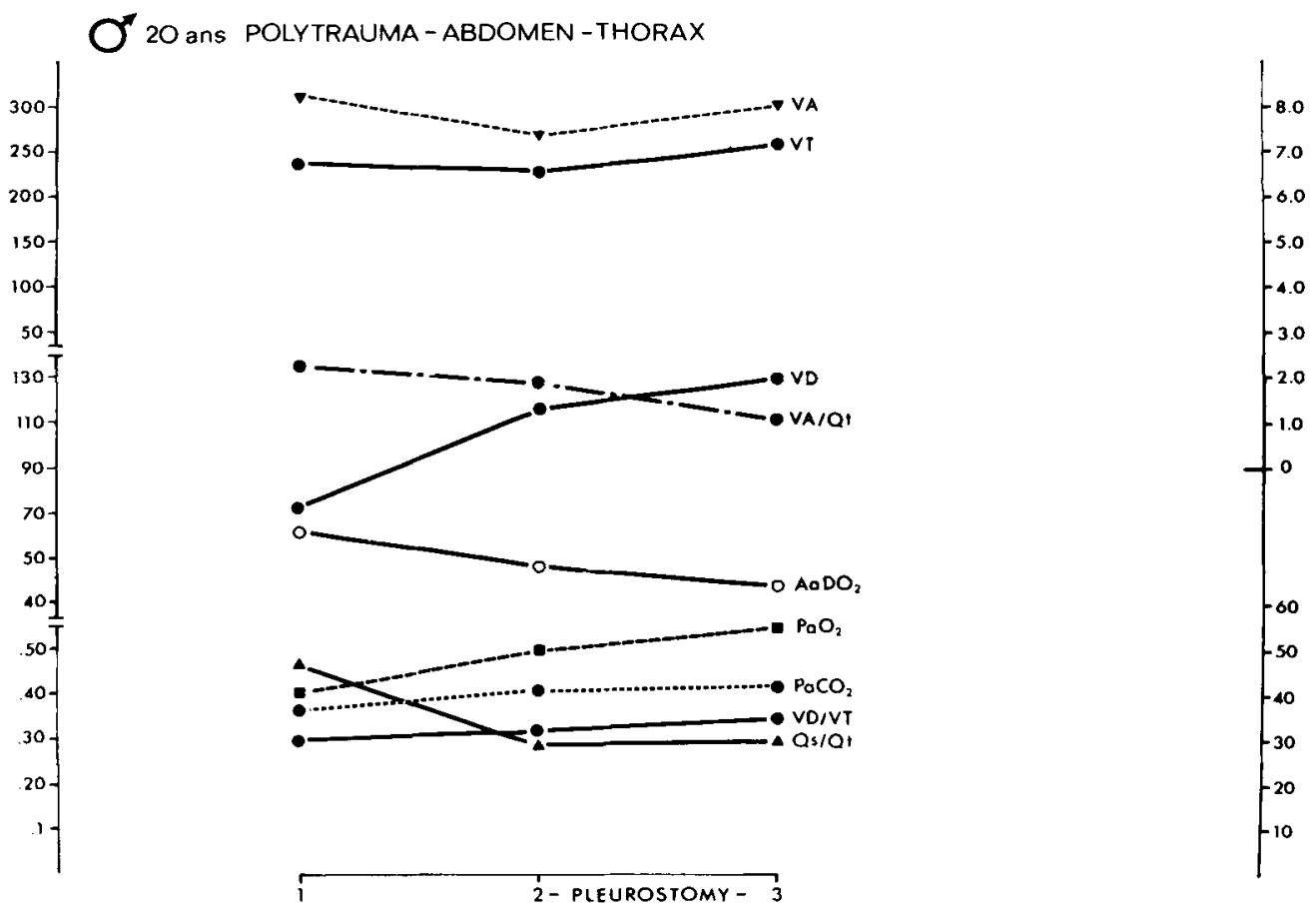

Frgure 3. Minimal improvement of respiratory function as compared to the dramatic enhancement of the cardiac performance.

\section{TABLE III}

Illustrates a Case of Acute Vascular Overload AFTER RESECTION OF AN ANEURYSM OF THE ABdominal AORTa

\begin{tabular}{|c|c|c|}
\hline \multicolumn{3}{|c|}{$\begin{array}{c}\text { Female: } 66 \text { years. Resection of Abdominal Aortic } \\
\text { Aneurysm }\end{array}$} \\
\hline & $09.45 \mathrm{hrs}$ & $10.45 \mathrm{hrs}$ \\
\hline VT ml BTPS & 677 & 279 \\
\hline $\mathrm{Vd} \mathrm{ml}$ BTPS & 336 & 86 \\
\hline $\mathrm{Vd} / \mathrm{Vt} \%$ & 0.49 & 0.31 \\
\hline VA litres/min & 7496 & 4146 \\
\hline $\mathrm{Va} / \mathrm{Qt}$ & 0.64 & 0.70 \\
\hline $\mathrm{Qs} / \mathrm{Qt}$ & 21.4 & 21.7 \\
\hline $\mathrm{AaDO}_{2}$ Torr & 43.9 & 43.3 \\
\hline $\mathrm{PaO}_{2}$ Torr & 68.9 & 74.3 \\
\hline $\mathrm{PaCO}_{2}$ Torr & 39.4 & 38.2 \\
\hline $\mathrm{CaO}_{2} \mathrm{ml} / 100 \mathrm{ml}$ & 14.67 & 14.87 \\
\hline $\mathrm{A}-\mathrm{V}$ diff $\mathrm{ml} / 100 \mathrm{cc}$ & 2.69 & 2.15 \\
\hline $\mathrm{VO}_{2} \mathrm{ml} / \mathrm{min} / \mathrm{m}^{2} \mathrm{STPD}$ & 202 & 82.2 \\
\hline $\mathrm{VCO}_{2} \mathrm{ml} / \mathrm{min} / \mathrm{m}^{2} \mathrm{STPD}$ & 174 & 74.7 \\
\hline & 0.859 & 0.908 \\
\hline$Q$ litres/min & 11.6 & 5.90 \\
\hline $\mathrm{HR}$ & 96 & $\begin{array}{r}100 \\
59\end{array}$ \\
\hline MAP Torr & $\begin{array}{l}120.9 \\
103.3\end{array}$ & 116 \\
\hline SVR dynes $/ \mathrm{sec} / \mathrm{cm}^{-5}$ & 697 & 1550 \\
\hline $\mathrm{CaO}_{2} \mathrm{ml} / \mathrm{min}$ & 1700 & 874 \\
\hline
\end{tabular}


Q 66 POST-OP ABD.-AORTO-AORTIC GRAFT-ANEURYSM
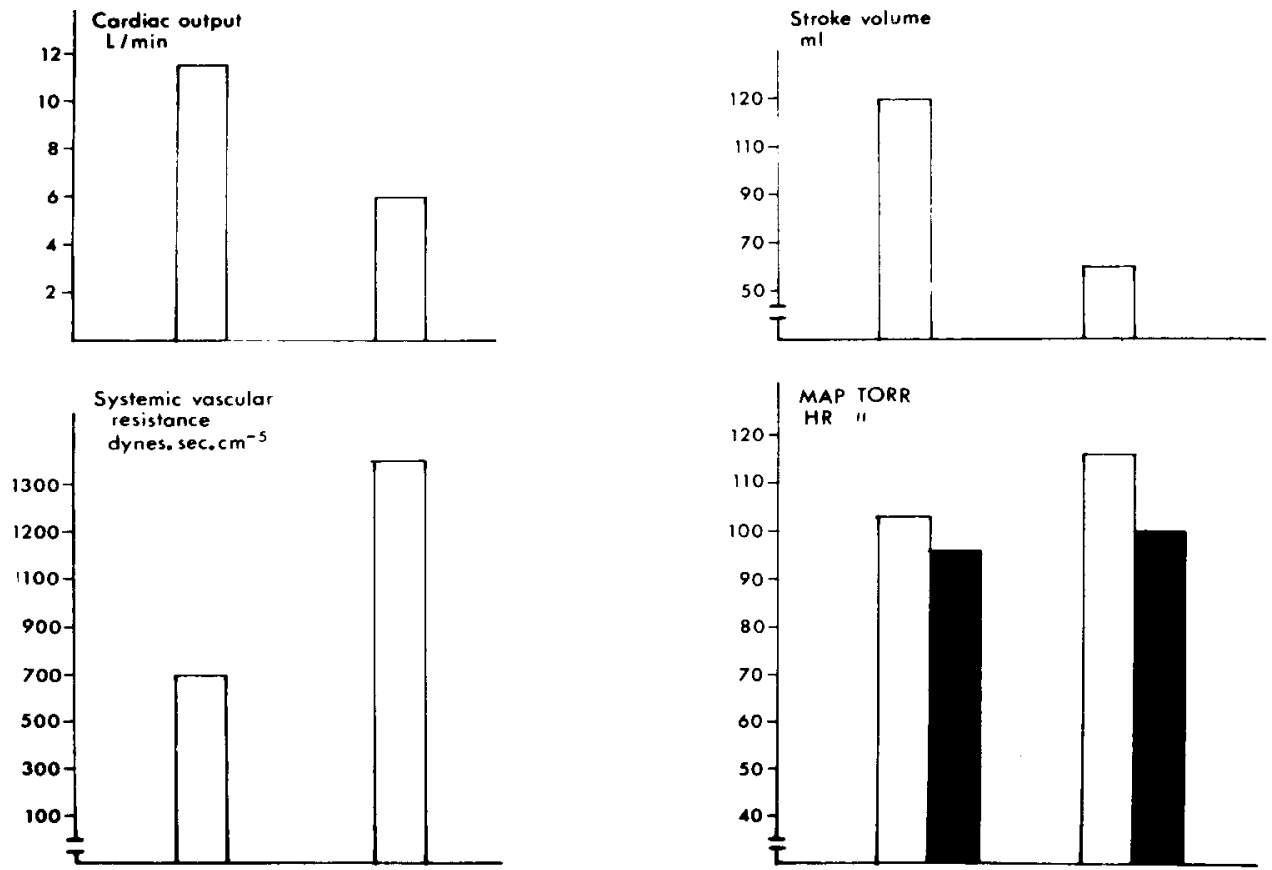

Figure 4. Hyperkinetic state after vascular overload in the post-operative period.

cardiac output did not alter the shunt nor the alveolar-arterial difference in any significant way, but the $\mathrm{Vd} / \mathrm{Vt}$ ratio was markedly decreased. This fluid overload and the marked cardiovascular changes that it generates, emphasize the dynamic changes encountered in the post-operative period of major surgery, especially in the aged ( Figures 4 and 5 ).

Another patient will demonstrate that circulation can be seriously jeopardized after major surgery. This 64-year-old man, suffering from arterio-sclerotic heart disease and chronic obstructive pulmonary disease, had an aorto-femoral bypass performed for bilateral aorto-femoral occlusion. In the post-operative period, heart rate was only slightly increased. Blood pressure was normal and pulmonary ventilation was also normal according to the $\mathrm{PaO}_{2}$ and $\mathrm{PaCO}_{2}$. Table IV illustrates the limitations of a clinical examination to fully assess the dynamics of geriatric patients. The Riley-Cournand analysis showed that 20 hours following operation the cardiac output decreased 40 per cent and that the BP remained normal because of a 50 per cent increase in total vascular resistance. Furthermore, the oxygen availability was markedly low and the alveolar-arterial difference in oxygen showed a two-fold increase. This patient had a very small reserve and a mere shivering episode could have proved disastrous (Figures 6 and 7 ). 

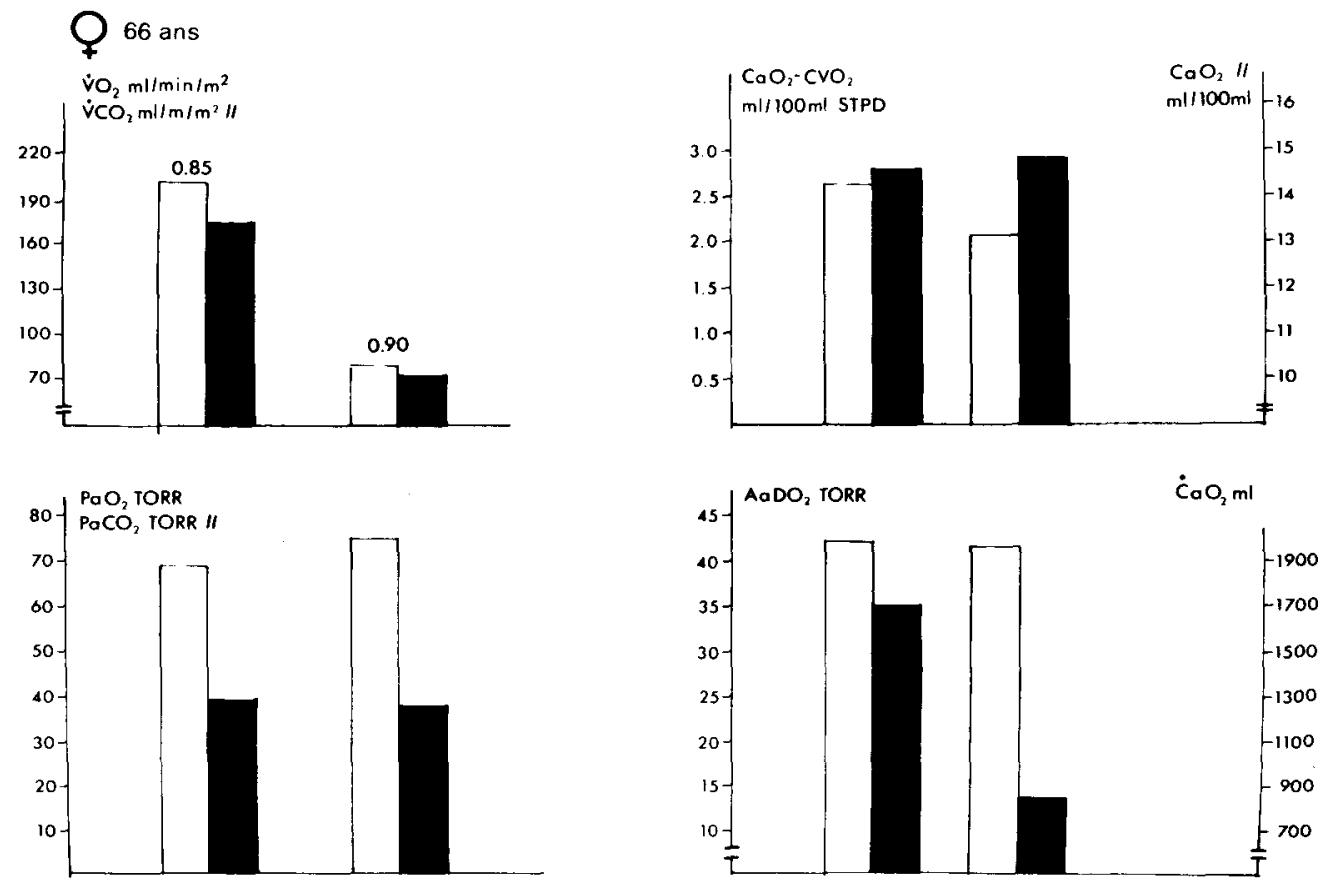

Figure 5. Same patient as in figure 4. The vascular overload had virtually no effect on blood gases and alveolar-arterial oxygen gradient.

TABLE IV

Illustrates the Limitations of a Clinical Examination to Fulliy Assess the Dynamics of Geriatric Patients

\begin{tabular}{|c|c|c|c|}
\hline \multicolumn{4}{|c|}{ Male: 64 years. Aorto-Femoral Graft $-\mathrm{ASHD}+\mathrm{COPD}$} \\
\hline & Pre-op. & Post-op. (4) & Post-op. (20) \\
\hline VT ml BTPS & 494 & 368 & 482 \\
\hline VD m1 BTPS & 252 & 167 & 236 \\
\hline $\mathrm{Vd} / \mathrm{Vt} \%$ & 0.51 & 0.45 & 0.48 \\
\hline VA litres/min & 3.5 & 6.5 & 5.3 \\
\hline $\mathrm{Va} / \mathrm{Qt}$ & 0.76 & 1.63 & 1.84 \\
\hline Qs/Qt & 11.6 & 5.9 & 9.1 \\
\hline $\mathrm{AaDO}_{2}$ Torr & 21 & 21.4 & 37 \\
\hline $\mathrm{PaO}_{2}$ Torr & 84 & 95 & 77 \\
\hline $\mathrm{PaCO}_{2}$ Torr & 36 & 35 & 34 \\
\hline $\mathrm{CaO}_{2} \mathrm{ml} / 100 \mathrm{cc}$ & 16.9 & 17.0 & 16.8 \\
\hline $\mathrm{A}-\mathrm{V}$ diff $\mathrm{ml} / 100 \mathrm{cc}$ & 2.61 & 4.01 & 5.58 \\
\hline $\mathrm{VO}_{2} \mathrm{ml} / \mathrm{min} / \mathrm{m}^{2}$ & 74.3 & 97.8 & 97.3 \\
\hline $\mathrm{VCO}_{2} \mathrm{ml} / \mathrm{min} / \mathrm{m}^{2}$ & 65 & 107 & 91.8 \\
\hline $\mathrm{R}$ & 0.87 & 1.10 & 0.94 \\
\hline $\mathrm{Q}$ litres/min & 4.65 & 3.98 & 2.88 \\
\hline $\mathrm{RC}$ & 100 & 98 & 100 \\
\hline SV ml & 46 & 40 & 28 \\
\hline MAP Torr & 113 & 121 & 109 \\
\hline SVR dynes $/ \mathrm{sec} / \mathrm{cm}^{-6}$ & 1859 & 2318 & 3017 \\
\hline $\mathrm{CaO}_{2} \mathrm{ml} / \mathrm{min}$ & 786 & 678 & 484 \\
\hline
\end{tabular}




\section{O $_{64 \text { ans }}$ AORTO-FEMORAL GRAFT ASHD. COPD}
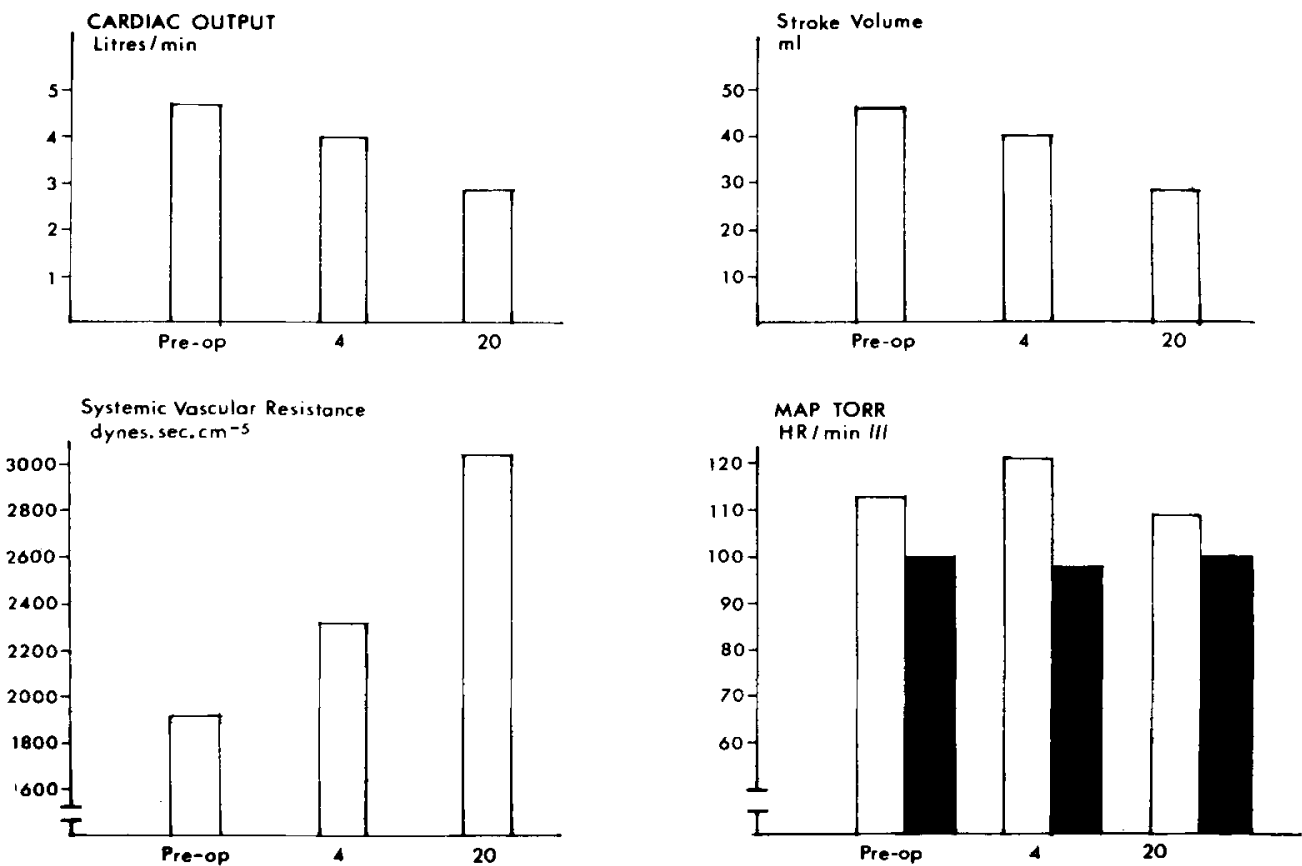

Figure 6. Blood pressure and heart rate do not reflect the severe cardiovascular changes in the post-operative period.

\section{CONCLUSION}

The actual clinical facts tend to indicate that the usual methods of assessing the state of patients who have suffered important trauma or major surgery are often insufficient. The Riley-Cournand analysis, besides giving important clues for the better care of patients, has an academic value in a teaching center and is a valuable research tool. With the help of the computer, it appears to be an essential instrument when the vital functions are taken over by the physician.

\section{RÉSUMÉ}

La ventilation mécanique à long terme, qui a contribué à sauver des vies autrefois perdues, a aussi aidé à créer de nouvelles complications: par exemple, le poumon de respirateur lorsque des concentrations élevées d'oxygène doivent être employées. Les méthodes ordinaires d'évaluation de l'état de ces patients deviennent insuffisantes. D'où la nécessité de trouver de nouveaux moyens tel l'analyse de Riley-Cournand qui, par la mesure de gaz expirés et l'analyse des gaz du sang artériel et veineux, peut nous donner, avec l'aide d'un ordinateur, une foule de renseignements inappréciables sur la dynamique cardiovasculaire et la fonction pulmonaire. Trois cas cliniques illustrent l'utilité de l'analyse de Riley-Cournand pour le traitement de cette catégorie de patients et prouvent sa valeur académique et son importance comme outil de recherche. 

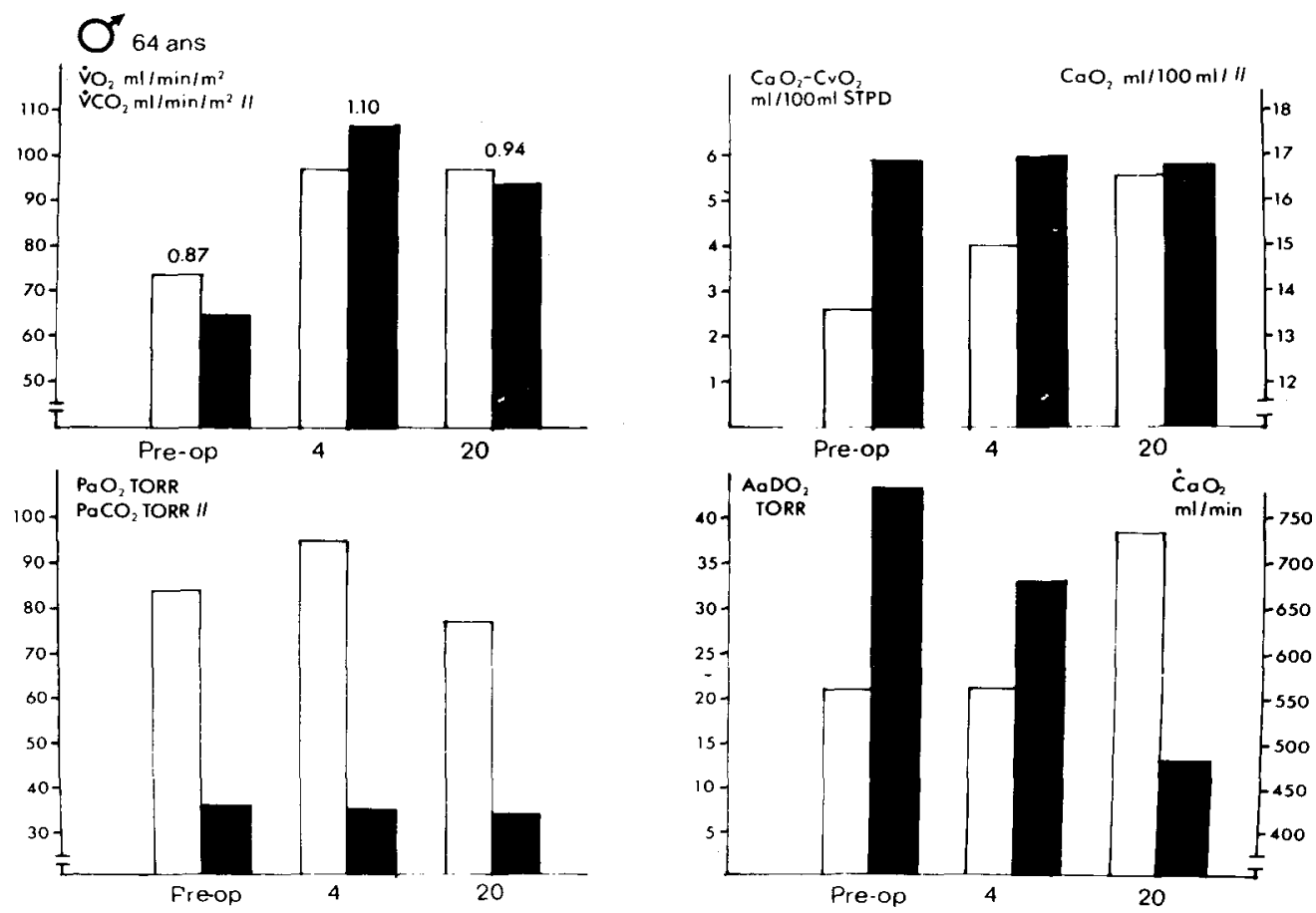

Figure 7. Blood gases and oxygen content do not reflect the severe impairment of cardiorespiratory function.

\section{ACKNOWLEDGMENT}

The authors wish to thank Mrs E. Boiselle and Mr J.C. Lanoue, and Mr R. Blanchard from the Computer Department for their precious help in preparing the program and the transcription interface.

\section{REFERENCES}

1. Engstrom, C.G. Treatment of severe cases of respiratory paralysis by the Engstrom respirator. Brit. Med. J. 666 (1952).

2. B JORK, V.O. \& ENGSTrom, C.G. The treatment of ventilatory insufficiency after pulmonary resection with tracheostomy and prolonged artificial ventilation. J. Thoracic Surg. 30: 356 (1955).

3. Bjonk. V.O. \& Engstrom, C.G. The treatment of ventilatory insufficiency by tracheostomy and artificial ventilation. J. Thoracic Surg. 34: 228 (1957).

4. SPENCER, S.C., Vincent, D.W., Lin, N.C., \& Bahrson, H.T. Use of a mechanical respirator in the management of respiratory insufficiency following trauma or operation for cardiac or pulmonary disease. J. Thoracic Sur. 38: 758 (1959).

5. Norlander, O.P., B Johk, V.O., Crafoord, C., Friberg, O., Holmdahl, N., Swensson, A., \& Widman, B. Controlled ventilation in medical practice. Anesthesia 15: 285 (1959).

6. Thung, N., Herzog, P., Christuneb, I.I., Thompson, W.M., \& Dammann, F.J. The cost of respiratory effort in post-operative cardiac patients. Circ. 28: 552 (1963).

7. Bendixen, H.H., Egbert, L.D., Hedley-White, J., et al. Respiratory care. St-Louis, C.V. Mosby Company, 1965.

8. Pontoppidan, H., Laver, M.B., \& GefFin, B. Acute respiratory failure in the surgical patient. Adv. Surg. 4: 163-254 (1970). 
9. Pontoppidan, H., Geffin, B., \& Lowenstein, E. Acute respiratory failure in the adult (first of three parts). N. Engl. J. Med. 287: 690-697 (1972).

10. Clark, J.M. \& Lambertsen, C.J. Pulmonary oxygen toxicity: a review. Pharmacol. Rev. 23: $37-133$ (1971).

11. LeE, C.I., Lyons, J.H., \& Konisberg, S., et al. Effects of spontaneous and positive pressure breathing of ambiant air and pure oxygen at one atmosphere pressure on pulmonary surface characteristics. J. Thoracic Cardiovasc. Surg. 53: 759-769 (1967).

12. Sladen, A., Laver, M.B., \& Pontoppidan, H. Pulmonary complications and water retention in prolonged mechanical ventilation. N. Engl. J. Med. 279: 448-453 (1968).

13. Nash, G., BlenNerhassett, J.B., \& Pontoppidan, H. Pulmonary lesions associated with oxygen therapy and artificial ventilation. New Engl. J. Med. 276: 368-374 (1967).

14. Fö̈x, P., Meloche, R., \& Prys-Roberts, C. Studies of anaesthesia in relation to hypertension: III Pulmonary gaz exchange during spontaneous ventilation. Brit. J. Anaesth. 43: 644 (1971).

15. Kelman, G.R. Digital computer subroutine for the conversion of oxygen tension into saturation. J. Appl. Physiol. 21: 1375 (1966).

16. Bradley, R.D. Diagnostic rightheart catheterisation with miniature catheters in severely ill patients. Lancet 2: 941 (1964).

17. Swan, H.J.C., Ganz, W., Forrester, T., et al. Catheterization of the heart in man with the use of a flow directed balloon tipped catheter. New Engl. J. Med. 283: 447-451 (1970).

18. Hedley-White, J. \& Winter, P.M. Oxygen therapy. Clin. Pharmac. and Ther. 8: 696737 (1967).

19. Severinghaus, J.W. Electrodes for blood and gaz $\mathrm{PCO}_{2}, \mathrm{PO}_{2}$ and blood pH. Acta Anaesth. Scand. Suppl. 11: 207 (1962).

20. SiggaArd-Andersen, $\mathrm{O}$. The $\mathrm{pH} \log -\mathrm{pCO}_{2}$ acid-base nomogram revised. Scand. J. Clin. Lab. Invest. 14: 598 ( 1962 ).

21. SCHOLANDER, P.F. Analyser for accurate estimation of respiratory gazes in one-half cubic centimeter samples. J. Biol. Chem. 167: 235-250 (1947).

22. Kelman, G.R. \& NunN, J.F. Nomograms for correction of blood $\mathrm{PO}_{2}, \mathrm{PCO}_{2}, \mathrm{pH}$ and base excess for time and temperature. J. Appl. Physiol. $21: 1484$ (1966).

23. EnghoFf, $H$. Volumen inefficax. Bemerkungen zur frage des schädlichen raumes upsala läk. Fören Förh, 44: 191 ( 1938 ).

24. NunN, J.F. Indirect determination of the ideal alveolar oxygen tension during and after nitrous oxide anaesthesia. Brit. J. Anaesth. 35: 8 (1963).

25. BergGreN, S.M. The oxygen deficit of arterial blood caused by non-ventilating parts of the lung. Acta physiol. Scand. suppl. 11 ( 1942 ).

26. Riley, R.L., Cournand, A., \& Donald, K.W. Analysis of factors affecting partial pressures of $\mathrm{O}_{2}$ and $\mathrm{CO}_{2}$ in gaz and blood of lungs: methods. J. Appl. Physiol. 4: 102 (1951).

27. FICK, A. Veber die messung des blutquantums in den herzventrikeln. Sifzungsb. der phys.med. Ges. Zu Wurzburg 36 ( 1870 ).

28. Perutz, M.S., Rossman, M.G., Culis, A.F., Mairhead, H., Nill, G., \& North, A.C.T. Structure of hemoglobin. A three dimensional fourier synthesis at 5.5-A resolution, obtained by X-ray analysis. Nature 185: 416 (London 1960).

29. Severinghaus, J.W. Blood gaz calculator. J. Appl. Physiol. 21: 1108 (1966).

30. Kelman, G.R. Digital computer subroutine for the conversion of oxygen tension into saturation. J. Appl. Physiol. 21 : 1375 (1966).

31. Kelman, G.R. Calculation of certain indices of cardiopulmonary function using a digital computer. Resp. Physiol. 1: 335 (1966). 